Tez Özeti

\title{
Olumlu ve Olumsuz Mesaj Stratejileri Bağlamında Siyasi Liderin Seçmen Algısı Üzerine Etkisi: 31 Mart 2019 Mahalli İdareler Seçimi Örneği*
}

\author{
Efe Numan Can (Arş. Gör.) \\ Aksaray Üniversitesi İletişim Fakültesi \\ efenumancan@gmail.com \\ ORCID: 0000-0002-4788-6553 \\ Hasan Güllüpunar (Prof. Dr.) \\ Süleyman Demirel Üniversitesi İletişim Fakültesi \\ hgullupunar@gmail.com \\ ORCID: 0000-0002-6479-6269
}

Bașvuru Tarihi: 04.09.2019

Yayına Kabul Tarihi: 04.11.2019

Yayınlanma Tarihi: 24.01.2020

DOI: http://10.17680/erciyesiletisim.615504

\section{Öz}

Liderlik en genel tanımıyla belirli bir amaç için bir grup insanı bir araya getirme, etkileme, yönlendirme ve harekete geçirme kabiliyetidir. Siyasi arenada da liderlik en önemli faktörlerden biridir. Ülkemiz siyasi tarihinin her aşamasında siyasi liderlerin olumlu ya da olumsuz etkileri olduğunu söylemek yanlış olmayacaktır. Bilhassa seçim süreçlerinde halkın karşısına çıkan ve onları ikna edip desteklerini almaya çalışan siyasi liderlerin mücadeleleri seçim sonuçlarına doğrudan etki etmiştir. Seçim sürecinde kullanılan stratejiler de savaş meydanlarında uygulananları aratmamıştır. Muktedir olmak isteyen siyasi aktörler bu bağlamda birbirlerine saldırmaktan veya negatif söylemlerde bulunmaktan kaçınmamışlardır. Bunun için her türlü siyasal iletişim faaliyeti kullanılmıştır. Bu faaliyetlerde olumlu ve olumsuz mesaj stratejileri de uygulanmıştır. Her toplum tarzı ne olursa olsun bir yönetim biçimine sahiptir. Bazı ülkeler güçlü seçim sistemlerine sahipken bazılarında saltanatlar, kabilecilik ya da diktatörlük hüküm sürmektedir. Demokratik sistemin yerleștiği toplumlarda iktidar, temsil yoluyla siyasal aktörlere devredilir. Bunun için seçimler yapılır ve çoğunluğun desteğini arkasına alan siyasi partiler belirli süreler için göreve gelirler. Bu süreç, birçok faktörün bir araya gelmesiyle işleyen bir mekanizmadır. Bu faktörler içerisinde siyasal liderliğin rolü oldukça önemli bir yer tutmaktadır. Özellikle Türkiye gibi siyasal katılım oranın yüksek olduğu ülkelerde siyasal liderler, çoğunlukla partileriyle özdeşleştirilmekte hatta kimi durumlarda partilerinin bile önünde yer almaktadır. Bu kapsamda Ak Parti ve CHP'nin 31 Mart 2019 Mahalli İdareler Seçimine yönelik yayınladıkları seçim beyannamelerinden elde edilen olumlu ve olumsuz mesajlar nitel içerik analizi yöntemiyle incelenmiş ve ölçek geliştirilerek katılımcılara yöneltilmiştir. Aksaray Üniversitesi'nin çeşitli bölümlerinde öğrenim gören 430 öğrenciyle yapılan araştırmada yapılan analizler neticesinde siyasi liderin kullandığı mesaj stratejilerinin katılımcılar üzerinde etkili olduğu anlașılmaktadır.

Anahtar Kelimeler: Liderlik, Seçim Kampanyaları, Mesaj Stratejileri.

\footnotetext{
* Bu çalışma, Erciyes Üniversitesi Sosyal Bilimler Enstitüsü’ne 2019 yılında sunulan “Olumlu Ve Olumsuz Mesaj Stratejileri Bağlamında Siyasi Liderin Seçmen Algısı Üzerine Etkisi: 31 Mart 2019 Mahalli İdareler Seçimi Örneği” başlıklı yüksek lisans tezinden türetilmiş makaledir.
} 


\title{
The Effect of Political Leader pn Voter Perception in the Context of Positive and Negative Message Strategies: The Case of 31 March 2019 Local Elections
}

\author{
Efe Numan Can (Res. Asst.) \\ Aksaray University Faculty of Communication \\ efenumancan@gmail.com \\ ORCID: 0000-0002-4788-6553 \\ Hasan Güllüpunar (Prof. Dr.) \\ Süleyman Demirel University Faculty of Communication \\ hgullupunar@gmail.com \\ ORCID: 0000-0002-6479-6269
}

Date Received: 04.09.2019

Date Accepted: 04.11.2019

Date Published: 24.01.2020

DOI: http://10.17680/erciyesiletisim.615504

\begin{abstract}
Leadership, in its most general definition, is the ability to bring together, influence, manipulate and mobilize a group of people for a particular purpose. Leadership is one of the most important factors in the political arena. It will not be wrong to say that political leaders have positive or negative effects at every stage of our country's political history. Especially in the electoral process, the struggles of political leaders who oppose the people and try to persuade them and get their support had a direct impact on election results. The strategies used in the election process are similar to those applied in battlefields. Political actors wishing to be able to do so did not avoid attacking each other or making negative statements. All kinds of political communication activities have been used for this purpose. Positive and negative message strategies were also implemented in these activities. Every society has a form of government, whatever its style. Some countries have strong electoral systems, while others are dominated by reigns, tribalism or dictatorship. In societies where the democratic system settles, power is transferred to political actors through representation. For this purpose, elections are held and political parties, which have the support of the majority, come to work for certain periods. This process is a mechanism that works by combining many factors. The role of political leadership is very important among these factors. Political leaders in countries with high political participation are often identified with their parties and sometimes even in front of them. In this context, the positive and negative messages obtained from the election declarations issued by Ak Parti and CHP for the March 31, 2019 Local Administrations Election were examined by qualitative content analysis method and the scale was developed and directed to the participants. As a result of the research conducted with 430 students studying at various departments of Aksaray University, it is understood that the message strategies used by the political leader were effective on the participants.
\end{abstract}

Keywords: Leadership, Election Campaigns, Message Strategies. 


\section{Giriş}

İktidar düşüncesi yüzyıllardır var olan bir olgudur. İnsanoğlu var olduğundan beri doğaya karşı, diğer canlılara karşı ya da birbirlerine karşı sürekli muktedir olmak için çabalamıştır. Zaman değişse de bu düşünce hiç değişmemiştir. İktidar kavgaları ve yönetimde söz sahibi olma düşüncesi günümüzün en büyük toplumsal çekişmelerinden biridir. Her toplum tarzı ne olursa olsun bir yönetim sistemine sahiptir. Bazıları güçlü seçim sistemlerine sahipken bazılarında saltanatlar, kabilecilik ya da diktatörlük hüküm sürmektedir. Demokratik sistemin yerleștiği toplumlarda iktidar temsil yoluyla siyasal aktörlere devredilir. Bunun için seçimler yapılır ve çoğunluğun desteğini arkasına alan siyasi partiler belirli süreler için göreve gelirler. Siyasal partiler toplumu ikna etmek ve desteğini alabilmek için plan ve program içerisinde hareket etmek durumundadırlar. $\mathrm{Bu}$ plan ve program içerisinde belirli stratejilerle rakiplerinden bir adım öne geçmenin hesapları yapılmaktadır. Cumhuriyetin ilanıyla birlikte ülkemiz meşrutiyetten parlamenter sisteme geçmiş ve demokrasi ile yönetilmeye başlanmıştır. Cumhuriyetle birlikte 1946'ya kadar tek partili dönem gerçekleşmiş ancak 1946 yılından sonra çok partili hayatın yolu açılmıştır. Tek partili dönemin aksine çok partili dönemde bir rekabet ortamına girilmiş ve siyasi partiler ve adaylar kıyasıya bir yarışa tutuşmuşlardır. Seçim kampanyaları çok önemli bir hal almıştır. Çok partili hayata geçişin ardından Adnan Menderes liderliğindeki Demokrat Parti yapmış olduğu kampanyayla büyük bir zafer elde etmiş ve yaklaşık on yıllık bir süreyle Türkiye'yi yönetmiştir. Demokrat Parti seçim kampanyası sırasında siyasi tarihimizin en etkili ve sade çalışmalarından biri olan "Yeter, söz milletindir!" sloganı ile meşhur afiş çalışmasını kullanmıştır. Afişte "dur" işareti ile bir el ve büyük puntolarla "yeter!" ifadesi yer alırken alt kısımda ise daha küçük boyutta "söz milletindir!" ifadeleri yer almaktadır (Devran, 2004, s. 15). Demokrat Parti'nin radyo ve afişlerle çok iyi bir şekilde başlatmış olduğu seçim kampanyaları günümüze kadar geliştirilerek devam etmiştir. Demokrasimiz çok partili hayata geçişten günümüze kadar kısmen darbeler, muhtıralar gibi siyaset dışı yöntemlerle kesintiye uğrasa da, günümüze kadar başarıyla uygulanagelmiştir. Teknolojik gelişmelere paralel olarak klasik seçim kampanyalarında kullanılan mitinglerin, afişlerin, radyonun yanına televizyon ve internetin eklenmesiyle çok daha zengin ve renkli kampanyalar ortaya çıkmıştır. Hatta günümüzde internet ve özelinde sosyal mecralar sayesinde canlı yayınla tüm siyasi parti adaylarının mitinglerine ulaşma imkânımız vardır. Bu nedenlerden dolayı seçimlerde başarılı olmak isteyen adaylar ve partiler artık profesyonel kampanya yöneticileri ile çalışmak zorunda kalmışlardır. Seçmenlerin oy verme davranışı üzerine Türkiye'de yapılan bir araştırmanın sonuçlarına göre siyasal partilerin kampanyalarına oy verenlerin oranı $\% 6$, siyasi partilerin programlarına oy verenlerin oranı $\% 17$, siyasi partilerin ekiplerine oy verenlerin oranı \% 25 iken; siyasi liderlere oy verenlerin oranı \% 38 ile en önemli faktörün siyasi liderler olduğunu ortaya koymuştur (Oluç, 2006, s. 96). Bu durum Türk siyasal yaşamında diğer faktörlere göre siyasi liderlerin ön plana çıktığını göstermektedir.

$\mathrm{Bu}$ çalışmada siyasi liderlerin olumlu ve olumsuz mesaj stratejileri bağlamında seçmen algısı üzerinde ne gibi bir etki bıraktığı tespit edilmeye çalışılmıştır. Bu kapsamda Ak Parti ve CHP'nin 31 Mart 2019 Mahalli İdareler Seçimi için yayınladıkları seçim beyannameleri içerik analizi yöntemiyle incelenmiş ve elde edilen olumlu ve olumsuz mesajlardan ölçek oluşturularak katılımcılara yöneltilmiştir. Çalışmanın temel amacı siyasi lidere duyulan güvenin olumlu ve olumsuz mesajların algılanma biçimine etkisini ele almaktır. Bu temel amaç çerçevesinde siyasi partilerin 31 Mart 2019 Mahalli İdareler Seçiminde hangi olumlu ve olumsuz mesajları kullandıkları, siyasi aktörlere duyulan güvenin kullanılan 
mesaj stratejilerinin seçmen tarafından algılanmasını etkileyip etkilemediği alt amaçlarla ortaya konulmaya çalışılmaktadır.

\section{Lider, Liderlik ve Siyasi Liderlik}

Kelime olarak lider ifadesi ilk defa Samuel Johnson tarafından 1755 yılında "kaptan, kumandan, önden giden kimse" olarak tanımlanmıștır (İbicioğlu; Özmen; Taș, 2009, s. 3). Türk Dil Kurumu sözlügünde lider kavramı "bir partinin veya bir kuruluşun en üst düzeyde yönetimiyle görevli kimse" olarak tanımlanmıştır. Buna paralel olarak liderlik kavramı ise önderlik veya liderin yapması gereken bir durum olarak belirtilmektedir. Lider, liderlik ve liderlik etmek kelimelerinin kökeni yol ya da yön anlamına gelen "lead" kelimesinden gelmektedir. Lider içinde bulunduğu grubu belirlediği amaçlar doğrultusunda yönlendiren ve onları davranışa sürükleyen kişidir (Erzen, 2008, s. 67). Hempfill ve Cons'a göre (1957) liderlik ortak bir amaç uğruna içinde bulunulan grubun davranışlarını yönlendirmeye çalışmak, Dubrin'e göre (1978) istenen amaçları gerçekleştirmeye çalışanları yönlendiren, onların sorunlarına çözüm bulan bir rol model, Rauch ve Behling'e göre (1984) belirli bir amacı gerçekleştirmek maksadıyla bir araya gelmiş bir grup insanın davranışlarını etkilemeye çalışma olarak tanımlanmaktadır (Zel, 2011, s. 109-110). Buradan hareketle şöyle bir liderlik tanımı yapılabilir; "belirli bir amacı gerçekleştirebilmek için bir grup insanı bir araya getirme, etkileyebilme ve harekete geçirme bilgi ve kapasitesine sahip olma durumudur". Literatürde bu tanımlara ilave olarak daha bir çok tanım yer almaktadır. Ancak ortak noktaları bir grup insanın olması, bir amaçlarının olması ve grubu etkileyecek ve manipüle edecek bir liderin olmasıdır (Zel, 2011, s. 110).

Liderler, kişisel özellikleri, takipçilerine karşı olan tutumları, karar alma sürecinde sergiledikleri yaklaşımlara göre farklı davranışlar sergilerler. Bu davranışlara göre literatürde en çok öne çıkan liderlik türleri; otokratik liderlik, katılımcı(demokratik) liderlik ve tam serbesti tanıyan liderliktir (Başarır, 2015, s. 71).

Liderliğin en ön plana çıktığı alanlardan birisi siyasettir. Liderlik, tüm alanlarda olduğu gibi siyasetin de vazgeçilmez bir parçası haline gelmiştir. Hatta günümüz siyasal yaşamında en kilit rollerden birini liderlik oynamaktadır. Siyasal partiler seçime girerken liderlerinin söyleyeceği her şey partinin alacağı oy oranına etki edecektir. Bu sebeple iyi bir lider, partisinin seçim stratejilerine göre hareket etmelidir.

Türkiye gibi siyasi katılım oranının çok yüksek olduğu yerlerde siyasi liderler genellikle partilerinin önünde yer almaktadır. Bu bağlamda hem siyasal yaşamda hem de hayatın diğer alanlarında, bütün grup ve insan ilişkilerinde insanlar takip edilen ve takip eden olmak üzere ikiye ayrılmaktadır. Liderler gerek vizyonları gerekse de karizmalarıyla bütünleștirici ve yol göstericidirler. Liderler ortalama olarak takipçilerinden daha zeki olmalıdır. Dahası takipçilerini etkileyebilmek için ilgili konudaki uzmanlık derecesi de takipçilerin lideri izlemesi için başlı başına önemli bir husustur (Teyfur ve Teyfur, 2018, s. 229). Bunlara ilaveten liderlerde olması gereken özellikler vardır.

Liderde bulunması gereken özellikler şunlardır (Neubeiser, 1999, s. 20):

- Devamlılık: Liderler amaçları doğrultusunda karşılarına engeller çıksa da yollarını değiştirmemelidirler.

- Tutarlılık: Liderlerin davranışları tutarlıdır. Söyledikleriyle yaptıkları arasında bir uyum söz konusudur. 
- Güvenilirlik: Liderler grubun, örgütün veya topluluğun tamamılyla güvenebileceği kişilerdir.

- Bütünlük: Liderler bir söz verdikleri zaman pürüzler çıksa da o sözü yerine getirirler.

Elbette tüm örgütlerin olduğu gibi siyasal partilerin de liderlere ihtiyacı vardır. Halkı temsil eden ve halk adına yönetimi sağlayan siyasal partiler bu anlamda lidere en çok ihtiyacı olan örgütlerdendir. Siyaset mali kaynakların dağıtımı, uzlaşı sağlama, hükmetme sanatı ve bunları yönlendirecek güce ulaşma ve bunu sürekli hale getirme olarak tanımlanmaktadır. Aynı zamanda siyaset adalet, para, erdem, vaat, tutku, hırs, şeref, haysiyet, sabır, çalışma gibi insanoğlunun hayatında önemli yerleri olan kavramları içinde barındırmaktadır (Erzen, 2008, s. 72). Göksu'ya göre (2018, s. 43) siyaset, iktidar olma ve bir ülkeyi yönetme amacı taşıyan kişiler ve kadroların yürüttüğü uzlaşı sanatıdır.

Liderler, toplumların gelişmesinde ve ilerlemesinde başat rol oynamakla beraber aynı zamanda toplumların çöküşünde ve bu sürecin hazırlanmasında da en büyük etmenlerden biridir. Liderin sahip olduğu kişisel özellikleriyle içinde bulunduğu toplumun özellikleri benzerlik gösterdiğinde, o toplumun gelişim süreci hızlanmakta ve pozitif yönde bir gelişim oluşmaktadır. Ancak tam tersine liderin sahip olduğu özellikler toplumla uyum içinde olmadığı durumlarda, topluma faydadan çok zararı dokunmaktadır (Akay, 2012, s. 78). Siyasal partilerin genel başkanları, siyasi yaşam içerisinde lider olarak algılanır ve liderlik kavramına da yöneticilikten farklı anlamlar yüklendiği bilinmektedir. Halk tarafından desteklenen bir parti liderinin en önemli özellikleri; dürüstlüğü, ileri görüşlülüğü, karakteri, güvenilirliği, hitap tarzı, üslubu, bilgi birikimi ve siyasi tecrübesi olarak gösterilebilir (Avcl, 2015, s. 152). Duverger'e göre (1975, s. 209) lider, kişisel açıdan sahip olduğu saygınlık, üstünlük ve çekicilik yüzünden kendisine itaat edilen kişi olarak tanımlanmıştır. Aydemir'e göre (1997, s. 14) lider bir önder şahsiyettir. Bu önder şahsiyet kendisine Allah tarafından verilen kabiliyetlerle beraber, yaşamı boyunca tecrübeleriyle ve edindiği kültürle oluşmaktadır. Ayrıca liderin kendini bilme ve disiplin özellikleri karakterini oluşturmaktadır.

Siyasi liderler seçmenleri etkileyebilmek ve onların desteğini alabilmek için her şeyden önce yaşadığı toplumu tüm boyutlarıyla tanımalı, toplumun taleplerini bilmeli, kendini bu talepleri karşılayacak biri olarak tanitmalı, toplumun beklentilerine göre sürekli kendini yenilemeli ve güven vermelidir. Siyasi liderlik, değişken bir ortamda belirli stratejik kararlar alabilmeyi ve belirlenen hedefler doğrultusunda izleyenleri bu hedefe yönlendirebilmeyi içerir (Erzen, 2008, s. 72-73). Yapılan araştırmalarda, seçmenlerin neden bir partiyi değil de, başka bir partiyi seçtiğini açıklamaya çalışan çok sayıda model ortaya konulmuştur. Seçmenler; politikalar, partinin konumu, ideoloji, etnik köken, kültürel ve manevi göstergeler, ekonomi, liderin gücü, konjonktürel faktörler gibi birçok koşuldan etkilenerek karar verirler. Seçmenler üzerinde bütün bu faktörler etkili olsa da, en önemli faktör liderlerdir. Çünkü seçimin kaderini değiştiren, seçimi kazanan ya da kaybeden liderlerdir (Özkan, 2014, s. 11). Liderlik araştırmalarında, klasik siyasi biyografi biçimlerine ilave olarak, liderin kişilik özelliklerinin ve çevresinin üzerinde yarattığı etkiden, liderin takip ettiği stratejilerin siyasi sonuçlarına kadar geniş bir yelpazede yaklaşımlar sergilenmiștir. Siyasi liderlik konusunda süregelen tartışmalar mevcuttur. Bunlar liderlerin hareketlerine çoğunlukla kişisel özellikler, hesaplar ve stratejiler açısından bakanlar ile siyasi sonuçları, bireylerin üzerinde çok az denetiminin olabildiği tarihi, toplumsal ve iktisadi güçlerin bir ürünü olarak görenler arasında cereyan etmektedir (Heper ve Sayarı, 2008, s. 9). 
Geçmişten günümüze tarihsel olarak sıralayacak olursak siyasal liderlik yaklaşımları genellikle Niccolo Machiavelli, Max Weber, İbn Haldun ve David Easton'un görüşlerine dayandırılarak tartışılmaktadır. Machiavelli'nin görüşleri zamanla Makyavelizm olarak adlandırılmıştır. Weber'in otorite tipleri üzerine detaylı çalışmalar yapılmış olsa da, Weber'in görüşlerinin geliştirilmesi pek mümkün olmamıștır (Göksu, 2018, s. 53).

\section{Seçim Kampanyalarında Mesaj Stratejileri}

Siyasi bir kampanya, sadece keyfi bir şekilde dizilen ve zamanlanan bir dizi olay ve etkinlik olmamalıdır. Mantıklı bir planın parçası olarak açık bir şekilde ortaya konulmalıdır. Faucheux kampanya yöneticisini bir satranç ustasına benzetiyor. Siyasi arenada kampanya yöneticileri satranç ustası gibi rakiplerinin hareketlerini önceden tahmin etmeli ve buna göre bir yol bulmalıdır. Strateji kendinizi nasıl konumlandırdığınız, güçlü yönlerinizi geliştirmek ve zayıf yönlerinizi minimum düzeye indirmek için kaynaklarınızı nasıl kullandığınızdır (Faucheux, 2002, s. 46-47). Siyasal kampanyalarda strateji "seçmen bizi neden tercih etmeli" sorusuna cevap vermelidir. Farklılıklar ön plana çıkartılmalıdır çünkü farklılıklar üzerine kurgulanan bir kampanyanın ikna gücü daha yüksek olacaktır. Ayrıca strateji belirlenirken adayın nitelikleri doğrultusunda hareket edilmelidir. Adayın, seçmenleri ikna etmeye yaracak özelliklerine yapılacak vurgu mesajların etkinliğini artıracaktır (Özkan, 2007, s. 127).

Devran'a göre (2004, s. 136) seçim kampanyalarında kullanılan dört farklı mesaj stratejisi bulunmaktadır. Bu stratejilerin kendi içinde her birinin avantajları ve dezavantajları vardır. Siyasal partiler ve adaylar kampanya sürecinde konumlarına, seçmen tercihlerine, anketlerin sonuçlarına, adayın oluşturulmak istenen imajına, partinin ideolojik yapısına ve kampanya bütçesine göre bu mesaj stratejilerinden bazılarını tercih edebilir. Hatta bazı durumlarda birden fazla mesaj stratejisi kullanılabilir. Siyasal kampanyalarda kullanılan başlıca mesaj stratejileri: Olumlu Mesaj Stratejisi, Olumsuz Mesaj Stratejisi, Reaktif (Tepkisel) Mesaj Stratejisi ve Aşlama Stratejisidir. Olumlu mesaj stratejisinde aday hiçbir zaman rakip aday veya partiye saldırmamakta ve rakiplerden gelebilecek kışkırtmalara cevap vermemektedir. ABD'de 1960 ve 1970'li yıllarda gerçekleştirilen seçim kampanyaları olumsuz mesaj stratejilerine sahne olsa da o dönemde siyasi kampanya yöneticileri bu stratejileri etkili bulmamışlardır. Olumsuz ve saldırı mesajlarının kaynaklarına geri döneceği ve seçmenlerin olumsuz kampanya mesajlarından hoşlanmadığı düşüncesiyle siyasal danışmanlar adaylara kendilerine saldırıldığı zaman görmezlikten gelinmesi gerektiğini söylemişlerdir (Johnson-Cartee ve Copeland, 1991, s. 8). Bu mantık bir süre Amerikan seçimlerinde uygulanmış ancak 1980'li yılların sonlarına doğru olumlu kampanya stratejilerinin yanında olumsuz kampanya stratejileri de kullanılmıștır. Eskiden beridir var olan iktidardaki parti veya adayın rakiplerinin saldırılarına cevapsız kalmalı çünkü onların saldırıları dikkate alınarak rakip adaylar yüceltilmemeli görüşü sonradan değişmiştir (Newman, 1999, s. 22).

Seçim kampanyalarında olumlu mesajların yanı sıra rakipler hakkında olumsuz mesajlarda kullanılabilir. Rakip aday hakkında olumsuz bir imaj yaratmak amacıyla geçmişteki yanlış icraatları, başarısızlıkları ve liderlik nitelikleri açısından yetersiz olduğu gibi konular gündeme getirilebilir. Olumsuz mesaj stratejisi uygulanacaksa öncelikle aday veya partilerin kendi politikaları, tutum ve davranışları gözden geçirilmeli sonra da eleştirecekleri aday ve partilerin artıları, eksileri, özellikleri detaylı bir şekilde analiz edilmelidir. Aksi halde sadece olumsuz mesaj stratejisi kullanmak için olumsuz mesajlar verilmemelidir (Devran, 2004, s. 140). 
Amerika'da 1964 yılında yapılan başkanlık seçimleri olumsuz mesaj stratejileri açısından milat olarak kabul edilmektedir. Lyndon Johnson tarafından rakip adaya yapılan sistemli saldırılar olumsuz mesaj stratejilerin Amerika'daki başlangıcı olarak kabul edilmektedir (Johnson-Cartee ve Copeland, 1991, s. 8). 23 Kasım 1963'te Amerikan Başkanı John F. Kennedy suikasta kurban gitmesiyle yardımcısı Lyndon Johnson Cumhuriyetçilerin adayı olmuştur. Demokratlar ise her firsatta savaşlarda atom bombasının kullanılabileceğini öne süren, Vietnam'ın atom bombasıyla dize getirilebileceğini belirten savaş taraftarı görüşleriyle tanınan Barry Goldwater'ı aday göstermiştir. Lyndon Johnson savaşlardan bıkmış Amerikan halkının beklentilerine uygun bir kampanyanın işe yarayacağını anlayarak üç ayrı film hazırlatır. Bu üç film içinde en başarılı olanı Daisy Spot(Papatya Spotu) olarak bilinen 30 saniyelik reklam filmidir. Filmde küçük bir kız çocuğu tarlada elinde bir papatya ile yürümektedir. Kamera kız çocuğunun gözünden girer ve dış ses çocuğun papatya yapraklarını sayışını nükleer bombanın geri sayımına dönüştürür. 10'dan geriye sayım bittiğinde bomba patlar ve "Çocukların mutlu bir şekilde yaşayacağı dünya ile karanlığa gömülecek bir dünya arasında seçim yapacaksınız. Ya birbirimizi seveceğiz ya da öldüreceğiz. 3 Kasım'da oyunuzu Johnson'a verin" sözleri duyulur. İkinci reklam filminde doğrudan Goldwater'ın ismi verilerek mesajlar verilirken üçüncü reklam filmi de diğer ikisi gibi nükleer bombalar üzerine kuruludur. Johnson bu seçimlerde olumsuz mesaj stratejisinin başarılı bir örneğini uygulayarak Amerikan tarihinin en farklı galibiyetlerinden birini alarak rakibine 17 milyon oy fark atmıştır (Özkan, 2014, s. 305; Devran, 2004, s. 141; Newman, 1999, s. 23). Devran'a göre (2004, s. 146) olumsuz mesajların kullanıldığı bir kampanyada mesajlar saldırı, ön saldırı ve aralıksız yoğun saldırı gibi farklı yoğunluklarda seçmene iletilebilir. Aynı zamanda olumsuz mesajlar doğrudan seçmene iletilebileceği gibi dolaylı ya da karşılaştırmalı bir şekilde de yöneltilebilir. Her bir olumsuz mesaj stratejisinin kendine özgü özellikleri vardır.

Reaktif mesaj stratejisi esasında adayların veya partilerin kendilerini rakip saldırılarına karşı korumak için bir savunma mekanizması görevi görmektedir. Diğer taraftan reaktif mesaj stratejisi uygulanırken saldırının geldiği kanallara benzer kanallar kullanılarak cevap verilmesi elzemdir. Örnek vermek gerekirse; eğer saldırı spesifik bir radyo istasyonu kullanılarak yapılmışsa tepkisel mesajlarda aynı ya da benzer radyo istasyonu üzerinden verilmelidir (Johnson-Cartee ve Copeland, 1997, s. 48-49).

Aşılama kavramı esasında siyasal kampanya iletişimine tıp biliminden geçmiştir. İnsanlar hastalandığında, virüslere veya hastalıklara karşı direncini artırmak için onlara virüslerin daha zaylf halleri enjekte edilir ve böylece insan vücudu bu virüslere karşı direnç kazanarak sonraki süreçlerde aynı virüs tarafından hastalığa yakalanması engellenmiş olur. Siyasal kampanya sürecinde de benzer bir durum söz konusudur. Bir aday rakiplerin vereceği olumsuz mesajlara ilişkin olarak kendi hedef kitlesini önceden bilgilendirerek ve onlara konunun esas yönlerini belirli düzeylerde anlatarak olumsuz mesajlara karşı direnç göstermelerini sağlamaktadır. Aksi halde seçmenler rakip adaylardan gelen bilgilerle hayal kırıklığına uğrayabilir hatta kanaatlerinde değişiklik olabilir (Devran, 2004, s. 156).

\section{Yöntem}

Bu çalışmada karma yöntem tercih edilmiştir. Karma yöntem literatürde henüz tüm araştırmacıların üzerinde uzlaştığı bir kavram değildir. Yöntemin ismiyle ilgili karma yöntem araştırması, karma model araştırması, karma desen araştırması, nitel ve nicel yöntemler, çoklu yöntemler, birleştirilmiş yöntemler ve karma yöntemleri en sık kullanılan kavramlardır. Bu kavramsal çeşitlilik karma yöntemin literatürde yeni olmasından 
kaynaklanmaktadır. Karma yöntem araştırma problemini kapsamlı ve çok boyutlu incelemek amacıyla, pragmatist felsefenin normları doğrultusunda hem nitel hem de nicel yöntemlerin bir arada kullanılarak gerçekleștirilen araştırma olarak tanımlanabilir (Yıldırım ve Şimşek, 2018, s. 322).

Araştırma kapsamında mesaj stratejileri bağlamında siyasi liderin seçmen algısı üzerindeki etkisini ortaya koyabilmek amaciyla 31 Mart 2019 Mahalli İdareler Seçiminde iktidar partisi olan Ak Parti ile ana muhalefet partisi olan CHP'nin seçim beyannameleri nitel içerik analizi ile incelenerek seçimlere yönelik hangi mesajları verdiği saptanmaya çalışılmıştır. Bu bağlamda Ak Parti ve CHP'nin 31 Mart 2019 seçimlerine yönelik yayımlanan seçim beyannameleri iki kodlayıcı tarafından içerik analizine tabi tutulmuştur. Her iki kodlayıcı da Ak Parti ve CHP için 50'şer adet mesaj üretmiştir. Başka bir ifade ile birinci kodlayıcı Ak Parti için 50, CHP için 50 olmak üzere toplam 100 mesaj üretirken; ikinci kodlayıcı da Ak Parti için 50, CHP için 50 olmak üzere 100 mesaj üretmiştir. Bu mesajların Ak Parti için \% 75'i olumlu, \% 25'i olumsuz, CHP için ise \% 63'ü olumlu, \% 37'si olumsuzdur. Genel toplam içerisindeki bu oranlar soru formuna aktarılırken aynı oranda olumlu ve olumsuz mesaj olmasına dikkat edilmiștir. İçerik analiziyle belirlenmiş olan olumlu ve olumsuz mesajlar ayrı ayrı torbalara konularak kura yöntemiyle ölçekler için seçilmiştir. Başka bir ifadeyle anket formunun ilk 25 yargılık ölçeği Ak Parti'nin seçim beyannamesinde yer alan olumlu ve olumsuz mesajlardan oluşmaktadır. İkinci 25 yargılık ölçek ise CHP'nin seçim beyannamesinde yer alan olumlu ve olumsuz mesajlardan oluşmaktadır. İlk iki bölümde bulunan 25'er yargılık iki ölçek 5'li Likert tarzında (1=Kesinlikle Güvenmiyorum - 2=Güvenmiyorum - 3=Kararsızım - 4= Güveniyorum 5=Kesinlikle Güveniyorum) oluşturulmuştur

Çalışmada nitel araştırma yöntemi olarak içerik analizi nicel araştırma yöntemi olarak anket tekniği kullanılmıştır. Anket formu 31 Mart 2019 Mahalli İdareler Seçimlerinin öncesinde aynı öğrenci grubuna iki defa uygulanmıştır. Birinci uygulama neticesinde keşfedici faktör analizi ile AK Parti Olumlu Mesajlar, Ak Parti Olumsuz Mesajlar, CHP Olumlu Mesajlar, CHP Olumsuz Mesajlar olmak üzere 4 faktör tespit edilmiştir. İkinci uygulama için ayrıca bir faktör analizi yapılmamıştır. Birinci uygulamada elde edilen faktörlere ait maddelerin aynısı ikinci uygulamada Ak Parti Lider Olumlu, Ak Parti Lider Olumsuz, CHP Lider Olumlu, CHP Lider Olumsuz olmak üzere 4 faktör daha oluşturulmuştur. Böylece birinci uygulama için 4, ikinci uygulama için de 4 olmak üzere toplam 8 faktör elde edilmiştir. Araștırmanın evrenini Aksaray Üniversitesi'nde 2018/2019 Eğitim Öğretim Yılı Bahar Yarıyllı'nda öğrenim gören lisans ve önlisans öğrencileri oluşturmaktadır. Örneklem yöntemi ise amaçlı örneklem olarak belirlenmiştir. Amaçlı örneklem yönteminin seçilmesinin temel sebebi anket formunun iki defa aynı öğrenci grubuna uygulanacak olmasıdır. Bu kapsamda araștırma 2018/2019 Eğitim Öğretim Yılı Bahar Yarıyılında Aksaray Üniversitesi'nde öğrenim gören lisans ve önlisans öğrencilerinden 430 ve 402 kişinin katılımıyla gerçekleştirilmiştir. Anket formu aynı öğrenci gurubuna birer hafta arayla iki defa uygulanmıştır. Birinci uygulamada ilk iki bölümde ölçeklerin başında bu mesajların hangi partilere ya da adaylara ait olduğu açıklanmamıştır. İkinci uygulama sırasında birinci ve ikinci bölümde mesajların hangi liderlere ait olduğu katılımcılara açıklanmış ve lider ile parti isimleri devreye girdiğinde katılımcıların tercihlerinde değişiklik olup olmadığı ölçülmeye çalışılmıştır.

Bu kapsamda araştırma hipotezleri şu şekilde belirlenmiştir: 
Hipotez 1: Siyasi lidere duyulan güven düzeyi siyasi partilerin kullandığı olumlu mesajların algılanışı üzerinde etkilidir.

- $\mathbf{H}_{\text {1.1.0: }}$ : Recep Tayyip Erdoğan'a duyulan güven düzeyinin Ak Parti ve CHP Olumlu Mesajlarının algılanışı üzerinde bir etkisi yoktur.

- $\mathbf{H}_{\text {1.1.1 }}$ : Recep Tayyip Erdoğan'a duyulan güven düzeyi Ak Parti ve CHP Olumlu Mesajlarının algılanıșı üzerinde etkilidir.

- $\mathbf{H}_{1.2 .0}$ : Kemal Kilıçdaroğlu'na duyulan güvenin Ak Parti ve CHP Olumlu Mesajlarının algılanışı üzerinde bir etkisi yoktur.

- $\mathbf{H}_{1.2 .1}$ : Kemal Kılıçdaroğlu'na duyulan güven düzeyi Ak Parti ve CHP Olumlu Mesajlarının algılanışı üzerinde etkilidir.

Hipotez 2: Siyasi lidere duyulan güven düzeyi siyasi partilerin kullandığı olumsuz mesajların algılanışı üzerinde etkilidir.

- $\mathbf{H}_{2.1 .0}$ : Recep Tayyip Erdoğan'a duyulan güvenin Ak Parti ve CHP Olumsuz Mesajlarının algılanışı üzerinde bir etkisi yoktur.

- $\mathbf{H}_{2.1 .1}$ : Recep Tayyip Erdoğan'a duyulan güven düzeyi Ak Parti ve CHP Olumsuz Mesajlarının algılanışı üzerinde etkilidir.

- $\mathbf{H}_{2.2 .0}$ : Kemal Kılıçdaroğlu'na duyulan güvenin Ak Parti ve CHP Olumsuz Mesajlarının algılanışı üzerinde bir etkisi yoktur.

- $\mathbf{H}_{2.2 .1}$ : Kemal Kılıçdaroğlu'na duyulan güven düzeyi Ak Parti ve CHP Olumsuz Mesajlarının algılanışı üzerinde etkilidir.

\section{Bulgular}

Araştırma toplam 450 kişi üzerinde yapılmış ancak eksik ve hatalı doldurulmuş 20 form iptal edilmiştir ve toplam 430 kişinin cevapları değerlendirmeye tabi tutulmuştur. Anket formu ilk uygulamadan bir hafta sonra aynı öğrenci grubuna tekrar yapılmıştır. 28 kişi ikinci uygulamaya katılmadığı için ikinci uygulamanın katılımcı sayısı ise 402 olarak gerçekleşmiştir.

\subsection{Betimleyici İstatistikler}

Tablo 1: Katılımcıların Sosyo-Demografik Özellikleri

\begin{tabular}{|c|c|c|c|c|c|}
\hline \multicolumn{3}{|c|}{ Birinci Uygulama } & \multicolumn{3}{c|}{ İkinci Uygulama } \\
\hline Cinsiyet & F & Yüzde & Cinsiyet & F & Yüzde \\
\hline Erkek & 181 & 42,1 & Erkek & 157 & 39,1 \\
\hline Kadın & 240 & 55,8 & Kadın & 239 & 59,5 \\
\hline Cevapsız & 9 & 2,1 & Cevapsız & 6 & 1,4 \\
\hline Toplam & 430 & 100 & Toplam & 402 & 100 \\
\hline \multicolumn{7}{|c|}{ Birinci Uygulama } & F & Yüzde & Yaş İkinci Uygulama & F & Yüzde \\
\hline Yaş & 185 & 43,0 & $18-20$ & 177 & 44 \\
\hline $18-20$ & 202 & 47,0 & $21-23$ & 189 & 47 \\
\hline $21-23$ & 22 & 5,1 & $24-26$ & 16 & 4 \\
\hline $24-26$ & 9 & 2,1 & $27-37$ & 13 & 3,2 \\
\hline $27-37$ & 12 & 2,8 & Cevapsız & 7 & 1,7 \\
\hline Cevapsız & 430 & 100 & Toplam & 402 & 100 \\
\hline Toplam & & & & & \\
\hline
\end{tabular}

Araştırmaya katılanların sosyo-demografik özellikleri frekans analizi yapılarak ortaya konulmuştur. Birinci ve ikinci uygulama için ayrı ayrı frekansları ve yüzdeleri 
hesaplanmıştır. Birinci uygulamaya katılanların \%42.1'ini oluşturan 181 kişi erkek, \% 55.8'ini oluşturan 240 kişi ise kadındır. İkinci uygulamada ise katılımcıların \% 39,1'ini oluşturan 157 kişi erkek, \% 59,5'ini oluşturan 239 kişi ise kadındır. Katılımcıların yaşları incelendiğinde birinci uygulamaya katılanların \% 43'ü 18-20 yaş, \% 47'si 21-23 yaş, $\%$ 5.1'i ise 24-26 yaș arasında iken; ikinci uygulamaya katılanların \% 44'ü 18-20 yaș, \% 47'si 21-23 yaş, \% 4'ü 24-26 yaş arasındadır. . Katılımcıların yaşları incelendiğinde birinci uygulamaya katılanların \% 43'ü 18-20 yaş, \% 47'si 21-23 yaş, \% 5.1'i ise 24-26 yaş arasında iken; ikinci uygulamaya katılanların \% 44'ü 18-20 yaş, \% 47'si 21-23 yaş, \% 4'ü 24-26 yaş arasındadır.

Tablo 2: Katılımcıların Siyasi Tercihleri

\begin{tabular}{|l|c|c|l|c|c|}
\hline \multicolumn{4}{|c|}{ Birinci Uygulama } & \multicolumn{3}{c|}{ İkinci Uygulama } \\
\hline $\begin{array}{l}\text { Kendinizi siyasal olarak } \\
\text { nasıl tanımlarsınız? }\end{array}$ & F & Yüzde & $\begin{array}{l}\text { Kendinizi siyasal olarak } \\
\text { nasıl tanımlarsınız? }\end{array}$ & F & Yüzde \\
\hline Muhafazakâr & 35 & 8,1 & Muhafazakâr & 38 & 9,5 \\
\hline Liberal & 9 & 2,1 & Liberal & 9 & 2,2 \\
\hline Sosyalist & 28 & 6,5 & Sosyalist & 31 & 7,7 \\
\hline Kemalist & 54 & 12,6 & Kemalist & 38 & 9,5 \\
\hline Milliyetçi & 168 & 39,1 & Milliyetçi & 173 & 43 \\
\hline Ulusalcı & 16 & 3,7 & Ulusalcı & 12 & 3 \\
\hline Demokrat & 52 & 12,1 & Demokrat & 57 & 14,2 \\
\hline İslamcı & 18 & 4,2 & İslamcı & 13 & 3,2 \\
\hline Diğer & 17 & 4,0 & Diğer & 22 & 5,5 \\
\hline Cevapsız & 33 & 7,7 & Cevapsız & 9 & 2,2 \\
\hline Toplam & 430 & 100 & Toplam & 402 & 100 \\
\hline
\end{tabular}

Katılımcılara yöneltilen "Kendinizi siyasal olarak nasıl tanımlarsınız?" sorusuna birinci uygulamada katılımcıların \% 39.1'i Milliyetçi cevabını verirken onu \% 12.6 ile Kemalist ve \% 12.1 ile de Demokrat cevabını verenler takip etmiştir. İkinci uygulamada ise katılımcıların \% 43'ü "Milliyetçi” cevabını vermiştir. Milliyetçi seçeneğini \% 14,2'lik oranla "Demokrat" cevabı izlemiştir. "Muhafazakâr" ve "Kemalist" seçeneklerin \% 9,5 ile aynı oranda kaldığı bu soruda en az orana \% 2,2 ile "Liberal" seçeneği sahip olmuştur. Birinci ve ikinci uygulama arasında benzer sonuçlar ortaya çıkmıştır.

\subsection{Faktör Analizi}

Keşfedici faktör analizi neticesinde ilk aşamada Ak Parti ve CHP'ye ait ölçekler için 2 ayrı faktör analizi uygulanmış ve her iki parti için 2'şer adet olmak üzere toplamda 4 faktör elde edilmiştir. İkinci aşamada, birinci aşamada elde edilen faktör maddelerinin ikinci uygulamadaki aritmetik ortalamalarından yeni faktörler oluşturulmuştur. Böylece toplam 8 faktör elde edilmiştir. 8 faktörün ortalama ve standart sapma değerleri aşağıdaki tabloda ifade edilmiştir. 
Tablo 3: Faktörlerin Betimleyici İstatistikleri

\begin{tabular}{|c|c|c|c|c|c|c|}
\hline & Faktörler & $\mathbf{F}$ & AO & SS & C.Alpha & Toplam Güvenilirlik \\
\hline \multirow{4}{*}{$\begin{array}{l}\text { Birinci } \\
\text { Uygulama }\end{array}$} & Ak Parti Olumlu Mesajlar & 430 & 2,97 & ,848 & ,924 & \multirow[b]{2}{*}{,899 } \\
\hline & $\begin{array}{l}\text { Ak Parti Olumsuz } \\
\text { Mesajlar }\end{array}$ & 430 & 3,88 & ,818 & ,689 & \\
\hline & CHP Olumlu Mesajlar & 430 & 3,01 & 917 & ,926 & \multirow{2}{*}{,942 } \\
\hline & CHP Olumsuz Mesajlar & 430 & 3,44 & 1,165 & ,912 & \\
\hline \multirow{4}{*}{$\begin{array}{l}\text { İkinci } \\
\text { Uygulama }\end{array}$} & $\begin{array}{l}\text { Ak Parti Lider } \\
\text { Olumlu Mesajlar }\end{array}$ & 402 & 2,99 & 1,093 & ,968 & \multirow{2}{*}{,972 } \\
\hline & $\begin{array}{l}\text { Ak Parti Lider } \\
\text { Olumsuz Mesajlar }\end{array}$ & 402 & 3,47 & 1,092 & ,859 & \\
\hline & $\begin{array}{l}\text { CHP Lider Olumlu } \\
\text { Mesajlar }\end{array}$ & 402 & 2,70 & 1,122 & ,967 & \multirow{2}{*}{,977 } \\
\hline & $\begin{array}{l}\text { CHP Lider Olumsuz } \\
\text { Mesajlar }\end{array}$ & 402 & 2,84 & 1,251 & 945 & \\
\hline
\end{tabular}

Ak Parti ve CHP'nin olumlu ve olumsuz mesajlarının yer aldığı anket formunda yer alan faktörlerin ortalamalarına baktığımızda katılımcıların en fazla önem verdikleri faktör 3,88 ortalama ile "Ak Parti Olumsuz Mesajlar" faktöründe gerçekleşmiştir. Katılımcıların en az önem verdikleri ortalama ise "CHP Lider Olumlu Mesajlar" faktöründe 2,70 ortalama ile gerçekleşmiştir. Diğer faktör ortalamaları ise "Ak Parti Lider Olumsuz Mesajlar" 3,47 ortalama, "CHP Olumsuz Mesajlar" 3,44 ortalama, "CHP Olumlu Mesajlar" 3,01 ortalama, "Ak Parti Lider Olumlu Mesajlar" 2,99 ortalama, "Ak Parti Olumlu Mesajlar" 2,97 ortalama, "CHP Lider Olumsuz Mesajlar" ortalama olarak gerçekleşmiştir. Birinci uygulama kapsamında elde edilen 4 faktörü oluşturan maddelerin ikinci uygulamadaki aritmetik ortalamaları üzerinden 4 faktör daha elde edilmiş ve toplamda 8 faktör oluşmuştur.

\subsection{Siyasi Aktörlere Güven Ölçeği Betimleyici İstatistikleri}

Tablo 4: Siyasi Aktörlere Güven Ölçeği İstatistikleri

\begin{tabular}{|c|c|c|c|c|c|c|c|}
\hline Maddeler & Kısa D. & Uygulama & $\mathbf{F}$ & Min & Max & AO & SS \\
\hline \multirow{2}{*}{$\begin{array}{l}31 \text { Mart Yerel Seçimlerinde, } \\
\text { seçim kampanyası sürecinde } \\
\text { Recep Tayyip Erdoğan'ın vermiş } \\
\text { olduğu mesajlara güveniyorum. }\end{array}$} & \multirow{2}{*}{ LiderRTE } & $\begin{array}{l}\text { Birinci } \\
\text { Uygulama }\end{array}$ & 425 & 1.00 & 10.00 & 5.21 & 3.327 \\
\hline & & $\begin{array}{l}\text { İkinci } \\
\text { Uygulama }\end{array}$ & 398 & 1.00 & 10.00 & 5.04 & 3.281 \\
\hline \multirow{2}{*}{$\begin{array}{l}31 \text { Mart Yerel Seçimlerinde, } \\
\text { seçim kampanyası sürecinde } \\
\text { Kemal Kılıçdaroğlu'nun vermiş } \\
\text { olduğu mesajlara güveniyorum. }\end{array}$} & \multirow{2}{*}{ LiderKK } & $\begin{array}{l}\text { Birinci } \\
\text { Uygulama }\end{array}$ & 424 & 1.00 & 10.00 & 3.17 & 2.785 \\
\hline & & $\begin{array}{l}\text { İkinci } \\
\text { Uygulama }\end{array}$ & 397 & 1.00 & 10.00 & 3.54 & 2.900 \\
\hline \multirow{2}{*}{$\begin{array}{l}31 \text { Mart Yerel Seçimlerinde, } \\
\text { seçim kampanyası sürecinde } \\
\text { Ak Parti'nin vermiş olduğu } \\
\text { mesajlara güveniyorum. }\end{array}$} & \multirow{2}{*}{ Ak Parti } & $\begin{array}{l}\text { Birinci } \\
\text { Uygulama }\end{array}$ & 426 & 1.00 & 10.00 & 4.88 & 3.270 \\
\hline & & $\begin{array}{l}\text { İkinci } \\
\text { Uygulama }\end{array}$ & 397 & 1.00 & 10.00 & 4.87 & 3.257 \\
\hline \multirow{2}{*}{$\begin{array}{l}31 \text { Mart Yerel Seçimlerinde, } \\
\text { seçim kampanyası sürecinde } \\
\text { CHP'nin vermiş olduğu } \\
\text { mesajlara güveniyorum. }\end{array}$} & \multirow{2}{*}{$\mathrm{CHP}$} & $\begin{array}{l}\text { Birinci } \\
\text { Uygulama }\end{array}$ & 423 & 1.00 & 10.00 & 3.48 & 2.835 \\
\hline & & $\begin{array}{l}\text { İkinci } \\
\text { Uygulama }\end{array}$ & 394 & 1.00 & 10.00 & 3.67 & 2.838 \\
\hline \multirow{2}{*}{$\begin{array}{l}31 \text { Mart Seçimlerinde, kampanya } \\
\text { sürecinde Cumhur İttifakı'nın vermiş } \\
\text { olduğu mesajlara güveniyorum. }\end{array}$} & \multirow{2}{*}{$\begin{array}{l}\text { Cumhur } \\
\text { İttifakı }\end{array}$} & $\begin{array}{l}\text { Birinci } \\
\text { Uygulama }\end{array}$ & 422 & 1.00 & 10.00 & 5.07 & 3.174 \\
\hline & & $\begin{array}{l}\text { İkinci } \\
\text { Uygulama }\end{array}$ & 394 & 1.00 & 10.00 & 4.93 & 3.166 \\
\hline
\end{tabular}




\begin{tabular}{|c|c|c|c|c|c|c|c|}
\hline Maddeler & \begin{tabular}{|l} 
Kısa D. \\
\end{tabular} & Uygulama & $\mathbf{F}$ & Min & Max & AO & SS \\
\hline \multirow{2}{*}{$\begin{array}{l}31 \text { Mart Seçimlerinde, kampanya } \\
\text { sürecinde Millet İttifakı'nın vermiş } \\
\text { olduğu mesajlara güveniyorum. }\end{array}$} & \multirow{2}{*}{$\begin{array}{l}\text { Millet } \\
\text { İttifakı }\end{array}$} & $\begin{array}{l}\text { Birinci } \\
\text { Uygulama }\end{array}$ & 409 & 1.00 & 10.00 & 3.73 & 2.899 \\
\hline & & $\begin{array}{l}\text { İkinci } \\
\text { Uygulama }\end{array}$ & 389 & 1.00 & 10.00 & 3.92 & 2.950 \\
\hline \multirow{2}{*}{$\begin{array}{l}31 \text { Mart Seçimlerinde, kampanya } \\
\text { sürecinde Ak Parti'nin Aksaray } \\
\text { Belediye Başkan Adayı Evren } \\
\text { Dinçer'in vermiş olduğu } \\
\text { mesajlara güveniyorum. }\end{array}$} & \multirow{2}{*}{$\begin{array}{l}\text { Yerel } \\
\text { Aday AKP }\end{array}$} & $\begin{array}{l}\text { Birinci } \\
\text { Uygulama }\end{array}$ & 416 & 1.00 & 10.00 & 4.76 & 3.012 \\
\hline & & $\begin{array}{l}\text { İkinci } \\
\text { Uygulama }\end{array}$ & 390 & 1.00 & 10.00 & 4.65 & 2.993 \\
\hline \multirow{2}{*}{$\begin{array}{l}31 \text { Mart Yerel Seçimlerinde, seçim } \\
\text { kampanyası sürecinde Millet İttifakı } \\
\text { kapsamında CHP'nin desteklediği } \\
\text { Aksaray Belediye Başkan Adayı } \\
\text { Özkan Türemiş'in vermiş olduğu } \\
\text { mesajlara güveniyorum. }\end{array}$} & \multirow[b]{2}{*}{$\begin{array}{l}\text { Yerel } \\
\text { Aday CHP }\end{array}$} & \begin{tabular}{|l|} 
Birinci \\
Uygulama
\end{tabular} & 399 & 1.00 & 10.00 & 3.37 & 2.813 \\
\hline & & $\begin{array}{l}\text { İkinci } \\
\text { Uygulama }\end{array}$ & 383 & 1.00 & 10.00 & 3.61 & 2.820 \\
\hline
\end{tabular}

Tablo 4 incelendiğinde siyasi aktörlere ait yargılara katılım açısından birinci uygulamada en yüksek ortalama "31 Mart Yerel Seçimlerinde, seçim kampanyası sürecinde Recep Tayyip Erdoğan'ın vermiş olduğu mesajlara güveniyorum” (5.21) yargısında gerçekleşmiştir. İkinci en yüksek ortalama "31 Mart Seçimlerinde, kampanya sürecinde Cumhur İttifakı'nın vermiş olduğu mesajlara güveniyorum” (5.07) yargısında gerçekleșmiştir. Sırasıyla diğer yargılar "31 Mart Yerel Seçimlerinde, seçim kampanyası sürecinde Ak Parti'nin vermiş olduğu mesajlara güveniyorum” (4.88), “31 Mart Seçimlerinde, kampanya sürecinde Ak Parti'nin Aksaray Belediye Başkan Adayı Evren Dinçer'in vermiş olduğu mesajlara güveniyorum" (4.76), "31 Mart Seçimlerinde, kampanya sürecinde Millet İttifakı'nın vermiş olduğu mesajlara güveniyorum” (3.73), "31 Mart Yerel Seçimlerinde, seçim kampanyası sürecinde CHP’nin vermiş olduğu mesajlara güveniyorum” (3.48), "31 Mart Yerel Seçimlerinde, seçim kampanyası sürecinde Millet İttifakı kapsamında CHP'nin desteklediği Aksaray Belediye Başkan Adayı Özkan Türemiş’in vermiş olduğu mesajlara güveniyorum" (3.37), şeklinde sıralanmıştır. En düşük ortalama ise (3.17) "31 Mart Yerel Seçimlerinde, seçim kampanyası sürecinde Kemal Kılıçdaroğlu'nun vermiş olduğu mesajlara güveniyorum" yargısında gerçekleşmiştir. Bu sonuçlar göstermektedir ki katılımcılar en çok Recep Tayyip Erdoğan'ın vermiş olduğu mesajlara güveniyorken; Kemal Kılıçdaroğlu'nun vermiş olduğu mesajlara güven düzeyi en az düzeydedir. İkinci uygulama sonuçlarına bakıldığında ise sıralamanın birinci uygulamayla aynı olduğu görülmektedir. Tablo 4'e göre en yüksek ortalamaya sahip yargı “Recep Tayyip Erdoğan'ın vermiş olduğu mesajlara güveniyorum" (5.04) olmuştur. En düşük ortalama birinci uygulamada olduğu gibi "Kemal Kılıçdaroğlu'nun vermiş olduğu mesajlara güveniyorum" (3.54) yargısında gerçekleşmiştir. Birinci uygulamada olduğu gibi katılımcılar en fazla Recep Tayyip Erdoğan'ın verdiği mesajlara güven duyarken; en az güven duyulan mesajlar Kemal Kılıçdaroğlu'na aittir. Her iki uygulama birlikte değerlendirildiğinde Recep Tayyip Erdoğan, Cumhur İttifakı, Ak Parti ve Evren Dinçer'in verdiği mesajlara güven durumu ikinci uygulamada birinci uygulamaya göre düşüş göstermiştir. Millet İttifakı, CHP, Özkan Türemiş ve Kemal Kılıçdaroğlu'nun verdiği mesajlarda ise birinci uygulamaya göre ikinci uygulamada bir artış söz konusudur. 


\subsection{Regresyon Analizi}

Tablo 5: Siyasi Aktörlere Duyulan Güven Düzeyinin Ak Parti Olumlu Mesajlarının Algılanması Üzerindeki Etkisi

\begin{tabular}{|c|c|c|c|c|c|c|c|c|c|}
\hline Uygulama & $\begin{array}{l}\text { Bağımlı } \\
\text { Değişken }\end{array}$ & Sabit D & B & Bağımsız D. & Sig & $\mathbf{t}$ & Tolerance & VIF & $\begin{array}{l}\text { Durbin } \\
\text { Watson }\end{array}$ \\
\hline \multirow{8}{*}{$\begin{array}{l}\text { Birinci } \\
\text { Uygulama }\end{array}$} & \multirow{8}{*}{$\begin{array}{l}\text { Ak Parti } \\
\text { Olumlu } \\
\text { Mesajlarının } \\
\text { Algılanması }\end{array}$} & \multirow{8}{*}{$\begin{array}{c}=2.111 \\
+\end{array}$} & .035 & Ak Parti & .249 & 1.155 & .126 & 7.914 & \multirow{8}{*}{1.853} \\
\hline & & & .067 & LiderRTE & .019 & 2.347 & .133 & 7.542 & \\
\hline & & & .011 & Yerel Aday AKP & .581 & .553 & .327 & 3.057 & \\
\hline & & & .053 & Cumhur İttifakı & .003 & 2.964 & .374 & 2.677 & \\
\hline & & & .024 & $\mathrm{CHP}$ & .420 & .807 & .170 & 5.888 & \\
\hline & & & -.027 & LiderKK & .354 & -.927 & .181 & 5.533 & \\
\hline & & & -.020 & Yerel Aday CHP & .324 & -.988 & .380 & 2.634 & \\
\hline & & & .027 & Millet İttifakı & .076 & 1.779 & .604 & 1.656 & \\
\hline \multicolumn{10}{|c|}{$R=, 599 ; R^{2}=, 345 ; F(8-390)=26.729 ; P=0,000$} \\
\hline Uygulama & $\begin{array}{l}\text { Bağımlı } \\
\text { Değişken }\end{array}$ & Sabit D & B & Bağımsız D. & Sig & $\mathbf{t}$ & Tolerance & VIF & $\begin{array}{c}\text { Durbin } \\
\text { Watson }\end{array}$ \\
\hline \multirow{8}{*}{$\begin{array}{l}\text { İkinci } \\
\text { Uygulama }\end{array}$} & \multirow{8}{*}{$\begin{array}{l}\text { Ak Parti } \\
\text { Lider Olumlu } \\
\text { Mesajlarının } \\
\text { Algılanması }\end{array}$} & \multirow{8}{*}{$\begin{array}{c}=1.936 \\
+\end{array}$} & .123 & Ak Parti & .004 & 2.934 & .072 & 13.961 & \multirow{8}{*}{1.989} \\
\hline & & & .089 & LiderRTE & .037 & 2.097 & .069 & 14.529 & \\
\hline & & & .039 & Yerel Aday AKP & .101 & 1.642 & .265 & 3.772 & \\
\hline & & & .007 & Cumhur İttifakı & .702 & .383 & .420 & 2.379 & \\
\hline & & & -.064 & $\mathrm{CHP}$ & .093 & -1.684 & .116 & 8.628 & \\
\hline & & & .055 & LiderKK & .151 & 1.438 & .111 & 9.013 & \\
\hline & & & -.026 & Yerel Aday CHP & .276 & -1.092 & .293 & 3.415 & \\
\hline & & & -.014 & Millet İttifakı & .442 & -.769 & .455 & 2.198 & \\
\hline
\end{tabular}

Mesaj stratejileriyle ilgili birinci uygulama kapsamında oluşturulan ilk faktör Ak Parti Olumlu Mesajlardır. Yapılan çoklu regresyon analizi neticesinde siyasi aktörlere duyulan güven düzeyinin Ak Parti Olumlu Mesajların algılanması üzerinde etkili olduğu şeklinde kurulan modelin anlamlı olduğu görülmektedir $(\mathrm{p}=.000)$. Modelin bağımsız değişkenlerini oluşturan siyasi aktörlere duyulan güven düzeyleri Ak Parti Olumlu Mesajlarının algılanmasını \% 34 oranında açıklamaktadır. Başka bir ifade ile Ak Parti Olumlu Mesajlarının algılanmasının \% 34'ü siyasi aktörlere duyulan güven düzeyleri üzerinden açıklanmaktadır. Siyasi aktörlere duyulan güven düzeylerinin her biri açısından Ak Parti Olumlu Mesajlarının algılanmasına bakıldığında "LiderRTE" ( $p=.019)$ ve "Cumhur İttifakı" ( $p=.003)$ değişkenlerinin bu algı üzerinde anlamlı bir etkiye sahip olduğu anlaşılmaktadır. "Ak Parti", "Yerel Aday AKP", “CHP”, "LiderKK", "Yerel Aday CHP" ve "Millet İttifakı" değișkenlerinin ise anlamlı $(p>, 050)$ bir etki oluşturmadığı görülmektedir. Buna göre Recep Tayyip Erdoğan'a duyulan güven düzeyinde meydana gelecek bir birimlik bir artış Ak Parti Olumlu Mesajlarının algılanmasını \% 7 oranında artıracaktır, Cumhur İttifakı'na duyulan güven düzeyinde meydana gelecek bir birimlik artış ise Ak Parti Olumlu Mesajlarının algılanmasını \% 5 oranında artıracaktır.

İkinci uygulamada Ak Parti Lider Olumlu Mesajlar faktörü ile yapılan çoklu regresyon analizi neticesinde siyasi aktörlere duyulan güven düzeyinin, Ak Parti Lider Olumlu Mesajların algılanması üzerinde etkili olduğu șeklinde kurulan modelin anlamlı olduğu anlaşılmaktadır $(\mathrm{p}=.000)$. Modelin bağımsız değişkenlerini oluşturan siyasi aktörlere duyulan güven düzeyleri Ak Parti Lider Olumlu Mesajlarının algılanmasını \% 57 oranında açıklamaktadır. Diğer bir ifade ile Ak Parti Lider Olumlu Mesajlarının algılanmasının \% 57'si siyasi aktörlere duyulan güven düzeyleri üzerinden açıklanmaktadır. Siyasi aktörlere 
duygulan güven düzeylerinin Ak Parti Lider Olumlu Mesajlar algısı üzerindeki etkilerine bakılacak olursa, "Ak Parti" ( $p=.004)$ ve "LiderRTE" ( $p=.037)$ değișkenlerinin bu algl üzerinde anlamlı bir etkiye sahip olduğu anlaşılmaktadır. "Yerel Aday AKP", "Cumhur İttifakı", "CHP”, "LiderKK", "Yerel Aday CHP” ve "Millet İttifakı" değişkenlerinin ise anlamlı ( $p>, 050)$ bir etki oluşturmadığı tespit edilmiştir. Bu sonuçlara göre Ak Parti'ye duyulan güven düzeyinde meydana gelecek bir birimlik artış "Ak Parti Lider Olumlu Mesajlar algısını \% 12 oranında artıracaktır. Recep Tayyip Erdoğan’a duyulan güven düzeyinde gerçekleșecek bir birimlik artış ise bu algıyı \% 9 oranında artıracaktır.

Tablo 6: Siyasi Aktörlere Duyulan Güven Düzeyinin Ak Parti Olumsuz Mesajlarının Algılanması Üzerindeki Etkisi

\begin{tabular}{|c|c|c|c|c|c|c|c|c|c|}
\hline Uygulama & $\begin{array}{l}\text { Bağımlı } \\
\text { Değişken }\end{array}$ & Sabit D & B & Bağımsız D. & Sig & $\mathbf{t}$ & Tolerance & VIF & $\begin{array}{l}\text { Durbin } \\
\text { Watson }\end{array}$ \\
\hline \multirow{8}{*}{$\begin{array}{l}\text { Birinci } \\
\text { Uygulama }\end{array}$} & \multirow{8}{*}{$\begin{array}{l}\text { Ak Parti } \\
\text { Olumsuz } \\
\text { Mesajlarının } \\
\text { Algılanması }\end{array}$} & \multirow{8}{*}{$=3.520+$} & -.067 & Ak Parti & .054 & -1.935 & .126 & 7.914 & \multirow{8}{*}{2.086} \\
\hline & & & .102 & LiderRTE & .002 & 3.111 & .133 & 7.542 & \\
\hline & & & .007 & Yerel Aday AKP & .773 & .288 & .327 & 3.057 & \\
\hline & & & .018 & Cumhur İttifakı & .392 & .857 & .374 & 2.677 & \\
\hline & & & .029 & $\mathrm{CHP}$ & .387 & .865 & .170 & 5.888 & \\
\hline & & & -.050 & LiderKK & .140 & -1.478 & .181 & 5.533 & \\
\hline & & & .018 & Yerel Aday CHP & .447 & .761 & .380 & 2.634 & \\
\hline & & & .006 & Millet İttifakı & .732 & .343 & .604 & 1.656 & \\
\hline \multicolumn{10}{|c|}{$R=, 274 ; R^{2}=, 056 ; F(8-390)=3.880 ; P=0,000$} \\
\hline Uygulama & $\begin{array}{l}\text { Bağımlı } \\
\text { Değişken }\end{array}$ & Sabit D & B & Bağımsız D. & Sig & $\mathbf{t}$ & Tolerance & VIF & $\begin{array}{c}\text { Durbin } \\
\text { Watson }\end{array}$ \\
\hline \multirow{8}{*}{$\begin{array}{l}\text { İkinci } \\
\text { Uygulama }\end{array}$} & \multirow{8}{*}{$\begin{array}{l}\text { Ak Parti } \\
\text { Lider } \\
\text { Olumsuz } \\
\text { Mesajlarının } \\
\text { Algılanması }\end{array}$} & \multirow{8}{*}{$=2.754+$} & .047 & Ak Parti & .368 & .901 & .072 & 13.961 & \multirow{8}{*}{2.021} \\
\hline & & & .068 & LiderRTE & .198 & 1.291 & .069 & 14.529 & \\
\hline & & & .040 & Yerel Aday AKP & .179 & 1.346 & .265 & 3.772 & \\
\hline & & & .042 & Cumhur İttifakı & .056 & 1.920 & .420 & 2.379 & \\
\hline & & & -.003 & $\mathrm{CHP}$ & .956 & -.056 & .116 & 8.628 & \\
\hline & & & -.024 & LiderKK & .607 & -.515 & .111 & 9.013 & \\
\hline & & & -.041 & Yerel Aday CHP & .172 & -1.368 & .293 & 3.415 & \\
\hline & & & .002 & Millet İttifakı & .939 & .076 & .455 & 2.198 & \\
\hline
\end{tabular}

Birinci uygulama kapsamında oluşturulan ikinci faktör Ak Parti Olumsuz Mesajlar faktörüdür. Siyasi aktörlere duyulan güven düzeyinin Ak Parti Olumsuz Mesajların algılanması üzerinde etkili olduğu șeklinde kurulan modelin anlamlı olduğu yapılan regresyon analizinden anlaşılmaktadır $(\mathrm{p}=.000)$. Kurulan modelin bağımsız değişkenleri olan siyasi aktörlere duyulan güven düzeyleri Ak Parti Olumsuz Mesajlar algısının \% 6’sını açıklamaktadır. Başka bir ifade ile Ak Parti Olumsuz Mesajlarının algılanmasının \% 6'sı siyasi aktörlere duyulan güven düzeyleri tarafından açıklanmaktadır. Siyasi aktörlere duyulan güven düzeyi değişkenleri ile Ak Parti Olumsuz Mesajlar arasında yapılan analize göre sadece "LiderRTE" ( $\mathrm{p}=.002)$ değişkeninin bu algı üzerinde anlamlı bir etkiye sahip olduğu anlaşılmaktadır. "Ak Parti”, "Yerel Aday AKP”, "Cumhur İttifakı", "CHP”, "LiderKK", "Yerel Aday CHP" ve "Millet İttifakı" değişkenlerinin ise anlamlı (p>,050) bir etki oluşturmadığı tespit edilmiştir. Bu sonuca göre Recep Tayyip Erdoğan’a duyulan güven düzeyinde meydana gelecek bir birimlik bir artış Ak Parti Olumsuz Mesajlarının algılanmasını \% 10 oranında artıracaktır. 
İkinci uygulamada yer alan Ak Parti Lider Olumsuz Mesajlar faktörü üzerinde siyasi aktörlere duyulan güven düzeylerinin etkisini ölçmek amacıyla yapılan regresyon analizine göre kurulan modelin anlamlı olduğu anlaşılmaktadır(p=.000). Siyasi aktörlere duyulan güven düzeylerinin Ak Parti Lider Olumsuz Mesajlar algısının \% 33'ünü açıkladığı tespit edilmiştir. Siyasi aktörlere duyulan güven düzeyleri ayrı ayrı ele alındığında ise hiçbir değişkenin Ak Parti Lider Olumsuz Mesajlar algısı üzerinde anlamlı bir etki yaratmadığı görülmektedir ( $\mathrm{p}>, 050)$. Birinci ve ikinci uygulama kapsamında Ak Parti Olumsuz Mesajlar ve Ak Parti Lider Olumsuz Mesajlar faktörlerinin algılanması üzerinde siyasi aktörlerin etkisini ölçmek amacıyla yapılan regresyon analizine göre sadece birinci uygulamadaki Ak Parti Olumsuz Mesajlarının algılanmasına Recep Tayyip Erdoğan'a duyulan güven düzeyinin etki ettiği anlaşılmaktadır.

Tablo 7: Siyasi Aktörlere Duyulan Güven Düzeyinin CHP Olumlu Mesajlarının Algılanması Üzerindeki Etkisi

\begin{tabular}{|c|c|c|c|c|c|c|c|c|c|}
\hline Uygulama & $\begin{array}{l}\text { Bağımlı } \\
\text { Değişken }\end{array}$ & Sabit D & B & Bağımsız D. & Sig & $\mathbf{t}$ & Tolerance & VIF & $\begin{array}{l}\text { Durbin } \\
\text { Watson }\end{array}$ \\
\hline \multirow{8}{*}{$\begin{array}{l}\text { Birinci } \\
\text { Uygulama }\end{array}$} & \multirow{8}{*}{$\begin{array}{l}\text { CHP Olumlu } \\
\text { Mesajlarının } \\
\text { Algılanması }\end{array}$} & \multirow{8}{*}{$=2.166+$} & -.003 & Ak Parti & .945 & -.069 & .126 & 7.914 & \multirow{8}{*}{1.844} \\
\hline & & & .103 & LiderRTE & .003 & 2.949 & .133 & 7.542 & \\
\hline & & & .011 & Yerel Aday AKP & .651 & .453 & .327 & 3.057 & \\
\hline & & & .020 & Cumhur İttifakı & .364 & .909 & .374 & 2.677 & \\
\hline & & & .062 & $\mathrm{CHP}$ & .086 & 1.722 & .170 & 5.888 & \\
\hline & & & -.007 & LiderKK & .834 & -.209 & .181 & 5.533 & \\
\hline & & & -.019 & Yerel Aday CHP & .435 & -.782 & .380 & 2.634 & \\
\hline & & & .010 & Millet İttifakı & .599 & .526 & .604 & 1.656 & \\
\hline \multicolumn{10}{|c|}{$R=, 452 ; R^{2}=, 188 ; F(8-390)=12.279 ; P=0,000$} \\
\hline Uygulama & $\begin{array}{l}\text { Bağımlı } \\
\text { Değişken }\end{array}$ & Sabit D & B & Bağımsız D. & Sig & $\mathbf{t}$ & Tolerance & VIF & $\begin{array}{l}\text { Durbin } \\
\text { Watson }\end{array}$ \\
\hline \multirow{8}{*}{$\begin{array}{l}\text { İkinci } \\
\text { Uygulama }\end{array}$} & \multirow{8}{*}{$\begin{array}{l}\text { CHP Lider } \\
\text { Olumlu } \\
\text { Mesajlarının } \\
\text { Algılanması }\end{array}$} & \multirow{8}{*}{$=1.962+$} & .062 & Ak Parti & .283 & 1.076 & .072 & 13.961 & \multirow{8}{*}{1.693} \\
\hline & & & -.100 & LiderRTE & .086 & -1.720 & .069 & 14.529 & \\
\hline & & & .037 & Yerel Aday AKP & .261 & 1.126 & .265 & 3.772 & \\
\hline & & & -.003 & Cumhur İttifakı & .909 & -.114 & .420 & 2.379 & \\
\hline & & & -.007 & $\mathrm{CHP}$ & .896 & -.131 & .116 & 8.628 & \\
\hline & & & .140 & LiderKK & .007 & 2.696 & .111 & 9.013 & \\
\hline & & & .022 & Yerel Aday CHP & .501 & .673 & .293 & 3.415 & \\
\hline & & & -.014 & Millet İttifakı & .442 & -.769 & .455 & 2.198 & \\
\hline
\end{tabular}

Çalışmada birinci uygulama kapsamında oluşturulan üçüncü faktör CHP Olumlu Mesajlar faktörüdür. Siyasi aktörlere duyulan güven düzeylerinin CHP Olumlu mesajlarının algılanması üzerinde etkilidir şeklinde kurulan modelin anlamlı olduğu anlaşılmaktadır $(\mathrm{p}=.000)$. Ayrıca siyasi aktörlere duyulan güven düzeyinin CHP Olumlu Mesajlar algısını \% 19 oranında açıkladı̆̆ı görülmektedir. Başka bir ifade ile CHP Olumlu Mesajlarının algılanmasındaki değişimin \% 19'u siyasi aktörlere duyulan güven düzeyleri tarafından açıklanmaktadır. Siyasi aktörlere duyulan güven düzeyi değişkenleri ayrı ayrı ele alındığında sadece "LiderRTE" ( $\mathrm{p}=.003)$ değişkeninin bu algı üzerinde anlamlı bir etkiye sahip olduğu anlaşılmaktadır. "Ak Parti", "Yerel Aday AKP", "Cumhur İttifakı", "CHP", "LiderKK", "Yerel Aday CHP" ve "Millet İttifakı" değişkenlerinin ise anlamlı $(p>, 050)$ bir etki oluşturmadığı tespit edilmiștir. Bu sonuca göre Recep Tayyip Erdoğan'a duyulan güven düzeyinde meydana gelecek bir birimlik bir artış CHP Olumlu Mesajlarının algılanmasını \% 10 oranında artıracaktır. 
CHP Lider Olumlu Mesajlar faktörü analiz yapılan bir diğer faktördür. Yapılan çoklu regresyon analizine göre siyasi aktörlere duyulan güven düzeyinin, CHP Lider Olumlu Mesajların algılanması üzerinde etkili olduğu şeklinde kurulan modelin anlamlı olduğu anlaşılmaktadır( $\mathrm{p}=.000)$. Modelin bağımsız değişkenlerini oluşturan siyasi aktörlere duyulan güven düzeyleri CHP Lider Olumlu Mesajlarının algılanmasını \% 25 oranında açıklamaktadır. Diğer bir ifade ile CHP Lider Olumlu Mesajlarının algılanmasının \% 25'i siyasi aktörlere duyulan güven düzeyleri üzerinden açıklanmaktadır. CHP Lider Olumlu Mesajlarının algılanmasına etki eden siyasi aktörlere güven düzeyi değişkenleri tek tek incelendiğinde sadece "LiderKK" ( $\mathrm{p}=.007)$ değișkeninin bu algı üzerinde etkili olduğu görülmektedir. "Ak Parti", "LiderRTE”, "Yerel Aday AKP", "Cumhur İttifakı", "CHP”, "Yerel Aday CHP" ve "Millet İttifakı" değişkenlerinin ise anlamlı (p>,050) bir etki oluşturmadığı tespit edilmiştir. $\mathrm{Bu}$ sonuca göre Kemal Kılıçdaroğlu'na duyulan güven düzeyinde meydana gelecek bir birimlik bir artış CHP Lider Olumlu Mesajlarının algılanmasını \% 14 oranında artıracaktır.

Tablo 8: Siyasi Aktörlere Duyulan Güven Düzeyinin CHP Olumsuz Mesajlarının Algılanması Üzerindeki Etkisi

\begin{tabular}{|c|c|c|c|c|c|c|c|c|c|}
\hline Uygulama & $\begin{array}{l}\text { Bağımlı } \\
\text { Değişken }\end{array}$ & Sabit D & B & Bağımsız D. & Sig & $\mathbf{t}$ & Tolerance & VIF & $\begin{array}{c}\text { Durbin } \\
\text { Watson }\end{array}$ \\
\hline \multirow{8}{*}{$\begin{array}{l}\text { Birinci } \\
\text { Uygulama }\end{array}$} & \multirow{8}{*}{$\begin{array}{l}\text { CHP } \\
\text { Olumsuz } \\
\text { Mesajlarının } \\
\text { Algılanması }\end{array}$} & \multirow{8}{*}{$=2.566+$} & -.045 & Ak Parti & .344 & -.948 & .126 & 7.914 & \multirow{8}{*}{1.764} \\
\hline & & & .126 & LiderRTE & .006 & 2.764 & .133 & 7.542 & \\
\hline & & & .034 & Yerel Aday AKP & .291 & 1.058 & .327 & 3.057 & \\
\hline & & & .022 & Cumhur İttifakı & .431 & .789 & .374 & 2.677 & \\
\hline & & & .060 & $\mathrm{CHP}$ & .207 & 1.264 & .170 & 5.888 & \\
\hline & & & -.048 & LiderKK & .306 & -1.025 & .181 & 5.533 & \\
\hline & & & -.008 & Yerel Aday CHP & .807 & -.245 & .380 & 2.634 & \\
\hline & & & .033 & Millet İttifakı & .183 & 1.334 & .604 & 1.656 & \\
\hline \multicolumn{10}{|c|}{$R=, 374 ; R^{2}=, 122 ; F(8-390)=7.744 ; P=0,000$} \\
\hline Uygulama & $\begin{array}{l}\text { Bağımlı } \\
\text { Değişken }\end{array}$ & Sabit D & B & Bağımsız D. & Sig & $\mathbf{t}$ & Tolerance & VIF & $\begin{array}{c}\text { Durbin } \\
\text { Watson }\end{array}$ \\
\hline \multirow{8}{*}{$\begin{array}{l}\text { İkinci } \\
\text { Uygulama }\end{array}$} & \multirow{8}{*}{$\begin{array}{l}\text { CHP Lider } \\
\text { Olumsuz } \\
\text { Mesajlarının } \\
\text { Algılanması }\end{array}$} & \multirow{8}{*}{$=2.163+$} & -.032 & Ak Parti & .626 & -.488 & .072 & 13.961 & \multirow{8}{*}{1.675} \\
\hline & & & -.061 & LiderRTE & .362 & -.912 & .069 & 14.529 & \\
\hline & & & .105 & Yerel Aday AKP & .005 & 2.821 & .265 & 3.772 & \\
\hline & & & -.025 & Cumhur İttifakı & .368 & -.902 & .420 & 2.379 & \\
\hline & & & -.002 & $\mathrm{CHP}$ & .977 & .029 & .116 & 8.628 & \\
\hline & & & .103 & LiderKK & .084 & 1.732 & .111 & 9.013 & \\
\hline & & & .038 & Yerel Aday CHP & .311 & 1.014 & .293 & 3.415 & \\
\hline & & & .067 & Millet İttifakı & .020 & 2.341 & .455 & 2.198 & \\
\hline
\end{tabular}

Birinci uygulama kapsamında oluşturulan CHP Olumsuz Mesajlar faktörünün algılanmasına siyasi aktörlere duyulan güven düzeyinin etkili olduğu şeklinde kurulan modelin anlamlı olduğu yapılan regresyon analizinden anlaşılmaktadır $(\mathrm{p}=.000)$. Kurulan modelin bağımsız değişkenleri olan siyasi aktörlere duyulan güven düzeyleri CHP Olumsuz Mesajlar algısının \% 12'sini açıklamaktadır. Başka bir ifade ile CHP Olumsuz Mesajlarının algılanmasının \% 12'si siyasi aktörlere duyulan güven düzeyleri tarafından açıklanmaktadır. Siyasi aktörlere duyulan güven düzeyi değişkenleri ayrı ayrı ele alındığında sadece "LiderRTE" ( $\mathrm{p}=.006)$ değişkeninin bu algı üzerinde anlamlı bir etkiye sahip olduğu anlaşılmaktadır. "Ak Parti”, "Yerel Aday AKP”, "Cumhur İttifakı", "CHP”, "LiderKK", "Yerel Aday CHP” ve "Millet İttifakı" değişkenlerinin ise anlamlı ( $p>, 050$ ) bir 
etki oluşturmadığı tespit edilmiştir. Bu sonuca göre Recep Tayyip Erdoğan'a duyulan güven düzeyinde meydana gelecek bir birimlik bir artış CHP Olumsuz Mesajlarının algılanmasını \% 13 oranında artıracaktır.

İkinci uygulama kapsamında oluşturulan CHP Lider Olumsuz Mesajlarının algılanmasına siyasi aktörlere duyulan güven düzeyinin etkisi olduğu yönünde kurulan modelin anlamlı olduğu anlaşılmaktadır( $\mathrm{p}=.000)$. Siyasi aktörlere duyulan güven düzeylerinin CHP Lider Olumsuz Mesajlarının algılanmasını \% 21 oranında açıkladığı Tablo 8'de belirtilmektedir. Başka bir deyiş ile CHP Lider Olumsuz Mesajlarının algılanmasındaki değişimin \% 21'i siyasi aktörlere duyulan güven düzeyi tarafından açıklanmaktadır. Siyasi aktörlere duyulan güven düzeyi değişkenlerine ayrı ayrı bakılacak olursa "Yerel Aday AKP" ( $\mathrm{p=}=.005)$ ve "Millet İttifakı" ( $\mathrm{p=}=.020)$ değişkenlerinin bu algı üzerinde etkili olduğu görülmektedir. "Ak Parti”, "LiderRTE”, “Cumhur İttifakı", “CHP”, "LiderKK” ve "Yerel Aday CHP" değişkenlerinin ise anlamlı bir etki oluşturmadığı anlaşılmaktadır ( $p>, 050)$. Buna göre Millet İttifakına duyulan güven düzeyinde meydana gelecek bir birimlik artış CHP Lider Olumsuz Mesajlarının algılanmasını \% 7 oranında artıracaktır. Ak Parti'nin Aksaray Belediye Başkan Adayı Evren Dinçer'e duyulan güven düzeyinde meydana gelecek bir birimlik artış ise CHP Lider Olumsuz Mesajlarının algılanmasını \% 11 oranında pozitif yönde etkileyecektir.

\section{Sonuç ve Değerlendirme}

31 Mart 2019 Mahalli İdareler Seçimi siyasi partilerin ittifaklar yaparak girdiği bir seçim olmuştur. Seçimin ismi mahalli idareler olsa da adeta bir genel seçim havasında geçmiştir. 31 Mart Mahalli İdareler Seçim sürecinde Ak Parti ve lideri Recep Tayyip Erdoğan ile CHP ve lideri Kemal Kılıçdaroğlu meydanlara inerek seçmeni ikna etmeye çalışmışlardır. Ak Parti ve MHP'nin kurduğu Cumhur İttifakı ile CHP ve İyi Parti'nin kurduğu Millet İttifakı Türkiye'nin çeşitli bölgelerinde belediye başkanlıklarını kazanmak için rekabet etmişlerdir. Seçim sürecinde siyasi parti liderleri seçmeni ikna edebilmek amacıyla çeşitli stratejiler uygulamışlardır. Mesaj stratejileri de kampanya sürecinde liderlerin ve partilerin kullandığı stratejilerin başında gelmektedir. Bu mesaj stratejilerinden en fazla kullanılanlar ise olumlu ve olumsuz mesaj stratejileridir. Olumlu mesaj stratejisi daha çok iktidar partileri ve liderleri tarafından tercih edilirken; olumsuz mesaj stratejisi muhalefet partileri ve liderleri tarafından kullanılmaktadır. Ancak 31 Mart 2019 Mahalli İdareler Seçimi sürecinde her iki parti daha çok olumlu mesajlar kullanmayı tercih etmişlerdir. Ak Parti ve CHP'nin seçim beyannamelerinden içerik analizi ile seçilen soruların Ak Parti için \% 75'i olumlu, \% 25'i olumsuz, CHP için ise \% 63'ü olumlu, \% 37'si olumsuzdur. Bu oranlar soru formunda ilgili partiye ait ölçekler olușturulurken aynı șekilde korunmuștur.

Yapılan faktör analizine göre katılımcıların en yüksek puan verdiği faktör Ak Parti Olumsuz Mesajlar olmuştur. Başka bir ifade ile birinci formda yer alan ve Ak Parti'ye ait olduğu belli olmayan olumsuz mesajların ortalaması daha yüksektir. Ortalamanın en düşük kaldığı faktör ise CHP Lider Olumlu Mesajlar faktörüdür. Diğer bir deyişle CHP lideri Kemal Kılıçdaroğlu'nun vermiş olduğu olumlu mesajlara katılım 8 faktör içerisinde en düşük ortalamaya sahiptir.

Tablo 9: Regresyon Analizi Özet

\begin{tabular}{|l|l|}
\hline ETKiLENEN MESAJ STRATEJiSi ALGISI & ETKiLEYEN SiYASi AKTÖR \\
\hline Ak Parti Olumlu Mesajlar & Recep Tayyip Erdoğan - Cumhur İttifakı \\
\hline Ak Parti Lider Olumlu Mesajlar & Ak Parti - Recep Tayyip Erdoğan \\
\hline Ak Parti Olumsuz Mesajlar & Recep Tayyip Erdoğan \\
\hline
\end{tabular}




\begin{tabular}{|l|l|}
\hline ETKiLENEN MESAJ STRATEJiSi ALGISI & ETKILEYEN SiYASi AKTÖR \\
\hline Ak Parti Lider Olumsuz & Yok \\
\hline CHP Olumlu Mesajlar & Recep Tayyip Erdoğan \\
\hline CHP Lider Olumlu Mesajlar & Kemal Kılıçdaroğlu \\
\hline CHP Olumsuz Mesajlar & Recep Tayyip Erdoğan \\
\hline CHP Lider Olumsuz Mesajlar & Millet İttifakı- Evren Dinçer \\
\hline
\end{tabular}

Recep Tayyip Erdoğan'a duyulan güven düzeyinin 5 mesaj stratejisinin algılanmasına doğrudan etki ettiği görülmektedir. Dolayısıyla en etkili siyasi aktör Recep Tayyip Erdoğan'dır denilebilir. Ayrıca siyasi aktörlere güven ölçeğinin hem birinci uygulama hem de ikinci uygulamadaki ortalamalarına bakıldığında Recep Tayyip Erdoğan'ın yine ilk sırada en fazla güven duyulan aktör olduğu doğrulanmaktadır.

Çalışma mesaj stratejileri ve siyasi liderlik hakkında literatürde yer alan az sayıdaki araştırmalara katkı sunacak olması nedeniyle önem taşımaktadır. Olumlu ve olumsuz mesaj stratejilerinin incelendiği bu çalışma bundan sonra yapılacak benzeri çalışmalar için yol gösterici olacaktır. Mesaj stratejileri içerisinde yer alan reaktif ve aşılama mesaj stratejileriyle ilgili yapılacak çalışmalar alana önemli katkılar sunabilir.

\section{Kaynakça}

Akay, R. A. (2012). Siyasal İletişim Danışmanı. Ankara: Nobel Yayın Dağıtım.

Avcl, K. (2015). 2014 Yerel Ankara Yerel Seçimlerinde Parti Lideri Faktörünün Seçmenin Oy Verme Kararına Etkisi. Gümüşhane Üniversitesi İletişim Fakültesi Elektronik Dergisi, 145-179.

Aydemir, Ş. S. (1997). Lider ve Demagog. İstanbul: Remzi Kitabevi.

Başarır, M. (2015). Siyasal İletişim Sürecinde Lider Üslubunun Seçmen Davranışındaki Rolü Üzerine Bir Araştırma. Selçuk Üniversitesi Sosyal Bilimler Enstitüsü Halkla İlişkiler ve Tanıtım Anabilim Dalı. Yayımlanmamış Doktora Tezi. Konya.

Devran, Y. (2004). Siyasal Kampanya Yönetimi: Mesaj, Strateji ve Taktikler. İstanbul: Odak İletişim.

Duverger, M. (1975). Siyaset Sosyolojisi. (Ș. Tekeli, Çev.) İstanbul: Varlık Yayınları.

Erzen, M. Ü. (2008). Siyasi Lider İmajlarının Seçimlerde Etkisi. İstanbul Üniversitesi İletişim Fakültesi Dergisi, 65-80.

Faucheux, R. A. (2002). Running for Office The Strategies, Techniques, and Messages Modern Political Candidates Need to Win Elections. M. Evans.

Göksu, O. (2018). Siyasal Liderlik ve Recep Tayyip Erdoğan'ın Liderlik Kodları. Konya: Literatürk Academia.

Heper, M. ve Sayarı, S. (2008). Türkiye'de Liderler ve Demokrasi . İstanbul: Kitap Yayınevi.

İbicioğlu, H., Özmen, İ. ve Taş, S. (2009). Liderlik Davranışı ve Toplumsal Norm İlişkisi: Ampirik Bir Çalışma. Süleyman Demirel Üniversitesi İktisadi ve İdari Bilimler Fakültesi Dergisi, 1-23.

Johnson-Cartee, K. S. and Copeland, G. A. (1991). Negative Political Advertising. New Jersey: Lawrance Erlbaum Associates Inc.

Johnston-Cartee, K. S. and Copeland, G. A. (1997). Manipulation of the American Voter: Political Campaign Commercials. London: Praeger Series in Political Communication. 
Neubeiser, M. L. (1999). Liderlik ve Büyü. İstanbul: Evrim Yayınevi.

Newman, B. I. (1999). The Mass Marketing of Politics. London: Sage Publications.

Oluç, M. (2006). Temel Pazarlama Kavramları. İstanbul: Beta Yayınları.

Özkan, N. (2014). Seçim Kazandıran Kampanyalar. İstanbul: Mediacat Yayıncılık.

Teyfur, M. ve Teyfur, E. (2018). Liderlik. Y. Çelikten içinde, Eğitim, Örgüt ve Liderlik (s. 234235). Konya: Eğitim Yayınevi.

Ylldırım, A. ve Şimşek, H. (2018). Sosyal Bilimlerde Nitel Araştırma Yöntemleri. Ankara: Seçkin Yayıncılık.

Zel, U. (2011). Kişilik ve Liderlik Evrensel Boyutlarıyla Yönetsel Açıdan Araştırmalar Teoriler ve Yorumlar. Ankara: Nobel Yayınları. 


\title{
The Effect of Political Leader pn Voter Perception in the Context of Positive and Negative Message Strategies: The Case of 31 March 2019 Local Elections
}

\author{
Efe Numan Can (Res. Asst.)
}

Hasan Güllüpunar (Prof. Dr.)

\section{Extended Abstract}

The idea of power is a fact that has existed for centuries. Ever since mankind has existed, it has endeavored to be constantly able to be against nature, against other living things, or against each other. Although time has changed, this thought has never changed. The fights of power and the idea of having a say in government is one of the greatest social conflicts of our time. Every society has a management system whatever its style. Some have strong electoral systems, while others have reigns, tribalism or dictatorship. In societies where the democratic system settles, power is transferred to political actors through representation. For this purpose, elections are held and political parties, which have the support of the majority, come to work for certain periods. Political parties have to act in plan and program in order to convince the society and get their support. Within this plan and program, certain strategies are calculated to be one step ahead of its competitors.

Although our democracy has been partially interrupted by non-political methods such as coups and memorandums since the transition to multi-party life, it has been successfully implemented until today. Parallel to the technological developments, the rallies, posters, radio and television were added to the classical election campaigns. Even today, thanks to the internet and social media in particular, we have the opportunity to reach the rallies of all political party candidates. For these reasons, candidates and parties who wanted to succeed in the elections were now forced to work with professional campaign managers. The proportion of voters on the campaign of political parties according to the results of a study conducted in Turkey on the voting behavior of voters by $6 \%$, the proportion of voters in the programs of political parties $17 \%$, the proportion of voters to the team of political parties, while 25\%; The rate of those who voted for the political leaders was $38 \%$ with the most important factor (Oluç, 2006, p. 96). This shows that political leaders come to the forefront in Turkish political life compared to other factors.

In this study, it has been tried to determine the effect of political leaders on voter perception in terms of positive and negative message strategies. In this context, the election declarations issued by Ak Parti and CHP for the March 31, 2019 Local Administrations Election were examined by content analysis method and the scale was formed from positive and negative messages obtained and directed to the participants. The main purpose of this study is to examine the effect of trust on political leader on perception of positive and negative messages. Within the framework of this main purpose, it is aimed to determine which positive and negative messages the political parties use in the March 31, 2019 Local Administrations Elections and whether the trust in political actors affects the perception of the message strategies used by the voters is tried to be revealed for sub-purposes.

The word leader was first described by Samuel Johnson in 1755 as, captain, commander, leader kimse (İbicioğlu; Özmen; Taş, 2009, p. 3). Leader is the person who directs the 
group in line with the aims it determines and drives them to behavior (Erzen, 2008, p. 67). Leaders behave differently according to their personal characteristics, attitudes towards their followers, and their approaches in decision-making. According to these behaviors, the most prominent types of leadership in the literature are; autocratic leadership, participatory (democratic) leadership and leadership that recognizes full freedom (Basarir, 2015, p. 71).

One of the areas where leadership is at the forefront is politics. Leadership has become an indispensable part of politics as in all fields. In fact, leadership plays one of the key roles in today's political life. As political parties enter the elections, everything their leaders will say will have an impact on the party's vote. Therefore a good leader should act in accordance with his party's electoral strategies.

According to Devran (2004, p. 136), there are four different message strategies used in election campaigns. Each of these strategies has advantages and disadvantages. Political parties and candidates may choose some of these message strategies according to their position in the campaign process, voter preferences, the results of the surveys, the image of the candidate, the ideological structure of the party and the campaign budget. In some cases even more than one message strategy can be used. The main message strategies used in political campaigns are: Positive Message Strategy, Negative Message Strategy, Reactive Message Strategy and Vaccination Strategy.

In this study, mixed method was preferred. The mixed method is not yet a concept that all researchers agreed on in the literature. Mixed method research, mixed model research, mixed pattern research, qualitative and quantitative methods, multiple methods, combined methods and mixed methods are the most commonly used concepts related to the name of the method. This conceptual diversity stems from the fact that the mixed method is new in the literature. The mixed method can be defined as the research carried out using a combination of both qualitative and quantitative methods in line with the norms of pragmatist philosophy in order to examine the research problem in a comprehensive and multidimensional way (Yıldırım \& Şimşek, 2018, p. 322).

Content analysis was used as qualitative research method and questionnaire technique was used as quantitative research method. The questionnaire was applied to the same group of students twice before 31 March 2019 Local Administrations Elections. As a result of the first application, the exploratory factor analysis identified four factors as AK Party Positive Messages, Ak Party Negative Messages, CHP Positive Messages, CHP Negative Messages. A factor analysis was not performed for the second application. The same items of the factors obtained in the first application, the second party in the AK Party Leader Positive, AK Party Leader Negative, CHP Leader Positive, CHP Leader Negative 4 factors were created. Thus, a total of 8 factors were obtained, 4 for the first application and 4 for the second application.

The population of the research consists of undergraduate and associate degree students studying in the Spring Semester of 2018/2019 Academic Year at Aksaray University. The sampling method is purposeful. The main reason for choosing the purposive sampling method is that the questionnaire will be applied to the same group of students twice. In this context, the research was carried out with the participation of 430 and 402 students from undergraduate and associate degree students studying at Aksaray University in the Spring Semester of 2018/2019 Academic Year. The questionnaire was applied to 
the same group of students twice in one week intervals. In the first application, it is not explained which parties or candidates belong to these messages at the beginning of the scales. During the second application, the leaders in the first and the second part of the messages are explained to the participants and the leader and party names are activated to determine whether there is a change in the preferences of the participants.

It is seen that the level of trust in Recep Tayyip Erdoğan directly affects the perception of 5 message strategies. Therefore, the most influential political actor is Recep Tayyip Erdoğan. In addition, when the averages of the scale of trust in political actors in both the first and second applications are examined, it is confirmed that Recep Tayyip Erdoğan is the most trusted actor in the first place.

Keywords: Leadership, Election Campaigns, Message Strategies. 